\title{
UNSUR RUPA DAN MAKNA PADA BUSANA PENGANTIN BETAWI
}

\author{
AYOENINGSIH DYAH WOELANDHARY
}

Received: 23 September 2019; Accepted: 23 Oktober 2019; Published: 5 November 2019

Ed. 2019; 3 (1): 001 - 011

\begin{abstract}
Bridal dress is found in all cultures in the archipelago, its existence is often used as a focal point for invited guests, so it is not surprising that fashion is one of the elements that most brides pay attention to. Variety of designs and modifications are made by designers and brides to wear, but in general the basic form is not removed, it is manifested in maintaining the spirit of cultural values embedded in it. The focus of this research is the Betawi regional wedding dress. This Betawi tribe is a tribe whose majority of the population used to be people who lived and settled in this region since the time of the formation of Batavia, they grew up and developed as a large ethnic group, the result of intermarriages and mixed marriages of various ethnic migrants. The form of acculturation can be seen in the designation of the clothes worn by the bride and groom, namely the wedding dress 'haji care' for the bride and groom, and the "rias besar dandanan care none pengantin cine" for the bride. In this study will reveal a lot of the elements of form and symbolic meaning embedded in it, then the method in this research is descriptive analysis with qualitative methods, the analysis process uses visual art review theory, descriptive in nature, where data and pictures will be broken down and explanations about various things relating to the visual elements in the object of research that have been redrawn with illustration techniques. The most interesting finding in this study is the existence of different absorption elements, in this Betawi bridal costume is in the bride costume thick with Chinese culture, but in the male costume, thick with nuances of Arabic culture, and as we know that in history two this culture really has a strong influence on the development and growth of Betawi people.
\end{abstract}

Keywords: the visual elements, bridal costume, Betawi.

\section{PENDAHULUAN}

Pernikahan atau perkawinan adalah sebuah kisah yang ditemukan hampir diseluruh kebudayaan manusia, dari sejak masa Hindu, Budha hingga Islam. Narasi tentang kisah perkawinan hadir dalam ragam latarbelakang dan dimensi, salah satunya kisah yang menampilkan tentang perkawinan dalam panil Borobudur, yang mengisahkan perkawinan antara Pangeran Sudana dan Bidadari berrnama Manohara. Dalam panil tersebut tampak sosok bidadari dalam balutan busana yang indah.
Memasuki masa kebudayaan selanjutnya, dimana keberadaan prosesi perkawinan sudah mulai terekam dengan jelas dalam bentuk visual, terekam dalam sebuah kartu pos yang menampilkan suasana perkawinan di daerah Jawa pada awal abad 1900-an berjudul 'Javaansche Bruid en Bruidegom-Temanten laki en prampoean di poelo Djawa' terlihat sepasang lelaki dan perempuan duduk tersila di atas sebuah permadani., keduanya menggunakan busana khusus dan aksesoris seperti kalung, gelang, penutup kepala, giwang dan lain 
sebagainya. Kuat diduga konsep menggunakan baju atau busana khusus dalam sebuah perkawinan telah terjadi sejak manusia mengenal bahan sandang berupa pakaian, terlebih dengan ditemukannnya artefak berupa manik-manik dan perhiasan yang kuat diduga berperan sebagai hiasan dan mas kawin dalam sebuah suku di berbagai wilayah, seperti di temukan di daerah Kalimantan, dimana suku Dayak Maloh dan suku Dayak Taman Mendalam menggunakan manik tersebut sebagai sarana pertunangan dan mas kawin pada masa tersebut.

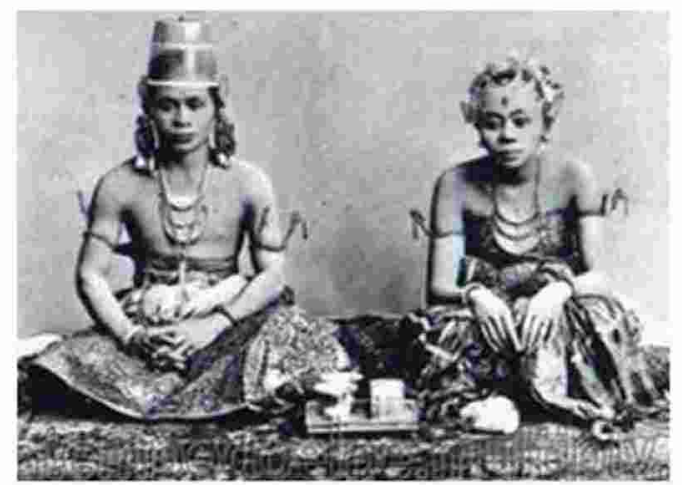

Gambar 1. Kartu pos yang diterbitkan sekitar awal tahun 1900-an yang berjudul

'Javaansche Bruid en Bruidegom-Temanten laki en prampoean di poelo Djawa' (sumber: istimewa)

Memasuki masa modern tradisi sebuah perkawinan dikemas dengan cara yang lebih meriah, walaupun konsep kebudayaan tetap dijadikan sebagai patokan dalam penyelenggaraanya. Salah satu yang paling menjadi fokus dalam acara perkawinan selain konsep acara, adalah busana pengantin yang digunakan. Peran busana pengantin menjadi penting karena merepresentasi konsep acara ritual sebuah kebudayaan yang digunakan memberi pada khalayak gambaran kearifan lokal, makna, simbol dan nilai budaya yang ditampilkan.

Fokus pada penelitian ini adalah busana pengantin daerah Betawi. Suku Betawi ini adalah suku bangsa yang mayoritas penduduknya dahulu adalah masyarakat yang tinggal dan menetap di wilayah ini sejak jaman pembentukan Batavia, mereka tumbuh dan berkembang sebagai etnis besar, hasil dari perkawinan sesama pribumi juga perkawinan campur dari aneka suku warga pendatang. Dalam referensi sejarah disebutkan bahwa Jakarta, yang dulu dikenal sebagai Batavia sebagai salah satu kota pelabuhan Jayakarta yang dikendalikan oleh perusahaan Hindia Timur Belanda (VOC), di masa penjajahan Belanda, sebagai wilayah perdagangan dan efek dari persilangan lalu lintas perlayaran dan perdagangan, percampuran budaya kian tidak terelakan. Kaum pendatang dari Arab, Cina, Melayu, Turki, Persia, India, hingga bangsa Eropa menciptakan kontak budaya dengan kebuyaan masyarakat setempat, bentuk akulturasi budaya terwujud dalam aneka bentuk, baik dari bahasa, kebiasaan, makanan, tingkah laku, busana dan lain sebagainya, namun bentuk kebudayaan asli dari suku Betawi tetap terlihat jati dirinya, yakni mengutamakan nilai religius dalam setiap aspek budayanya. Cermin religius terlihat pada jenis busana pengantin masyarakat Betawi yang hingga kini masih digunakan yang disebut busana pengantin 'care haji' bagi calon pengantin pria. Penamaan tersebut diduga mengadopsi unsur kebudayaan Arab, sedangkan bagi pengantin perempuan unsur busananya tampak didominasi unsur kebudayaan Cina, yang sering disebut dengan istilah "rias besar dandanan care none pengantin cine".

Dalam penelitian ini akan banyak mengungkap unsur rupa dan makna simbolik yang tertanam di dalamnya, maka metoda dalam penelitian ini berupa analisa deskriptif dengan metoda kualitatif, proses analisa menggunakan teori tinjauan seni rupa, bersifat deskriptif, dimanaakan di urai data dan gambar serta penjelasan tentang berbagai hal yang berkaitan dengan elemen visual dalam objek penelitian yang telah digambar ulang dengan teknik ilustrasi. Sesuai dengan sifat metode penelitian ini, dimana data dan fakta diperoleh dari 
sejumlah referensi, wawancara kepada narasumber didapat agar data yang diperoleh maksimal, maka pendekatan kualitatif dengan sifat sumber data adalah situasi yang wajar atau natural setting. Data dan fakta yang ditemukan di lapangan diverifikasi, baik dengan pendekatan emic maupun epic. Emic dimaknai sebagai sumber data bersandar pada hasil wawancara dari narasumber, sedangkan pendekatan epic lebih menekankan sumber data dari sejumlah referensi baik dari buku, jurnal, teks book dan lainnya.Pendekatan estetik, juga dilakukan untuk mengidentifikasi temuan pada objek dengan melihat wujud visual mulai dari bentuk, warna, dan komposisi ragam hias dan unsur lainnya. Hal ini agar mengungkap dugaan apakah unsur rupa tersebut di dalamnya ada nilai-nilai dalam bentuk simbol atau filosofi yang ditanamkan dari alam fikir para nenek moyang kepada para generasi penerus agar tetap menjaga keluhuran serta spirit kebudayaan yang mereka wariskan. Batasan masalah pada penelitian ini hanya menganalisa unsur rupa pada beberapa elemen saja, yang memang sarat dengan makna simbolik di dalamnya, seperti pada jubah, baju, hiasan kepala dan beberapa kelengkapan lainnya.

\section{Busana Pengantin di Nusantara}

Busana didefinisikan jenis busana yang dikenakan pada sebuah kegiatan. Busana pengantin dapat disebut sebagai busana khusus yang digunakan oleh pengantin yang dikenakan dari atas hingga bawah, dapat berupa apapun, yang intinya untuk menutupi, menghiasi dan melindungi tubuh. Penggunaan busana pengantin telah berlangsung sejak masa kerajaan, banyak catatan sejarah yang mengisahkan megahnya sebuah upacara perkawinan dari keluarga kerajaan yang saat itu tengah berkuasa. Beberapa artefak memperlihatkan ada perbedaan busana yang digunakan dalam sebuah perayaan besar dan busana yang dikenakan dalam sebuah peribadatan. Hal yang paling mencolok adalah jenis pakaian yang dikenakan oleh kalangan raja umumnya terlihat lebih mewah dengan beragam aksesoris, mulai dari kalung, gelang, mahkota hingga kain. Gambaran busana pengantin yang digunakan kalangan kerajaan maupun kalangan bangsawan di masa lalu banyak terekam dalam sejumlah literasi, salah satu yang sangat terlihat unsur kelengkapan umumnya terdiri atas busana bagian atas-bawah serta aksesoris, sedangkan material berupa kain, serat, baju, celana, sarung, logam dan lainnya. Penggunaan dan bentuk yang digunakana memiliki dan makna simbolis masing-masing, pada umumnya semua yang dikenakan berkait dengan filosofi hidup yang diyakini masyarakat setempat, karena di wilayah Indonesia pernikahan dikategorikan dalam kegiatan bersifat sakral dan bersifat tradisi, hingga sering dijumpai pula adanya pakem atau ritual yang terkadang sifatnya tidak boleh dilanggar oleh sang calon pengantin. Beikut adalah data visual keberadaan busana pengantin dari berbagai masa :

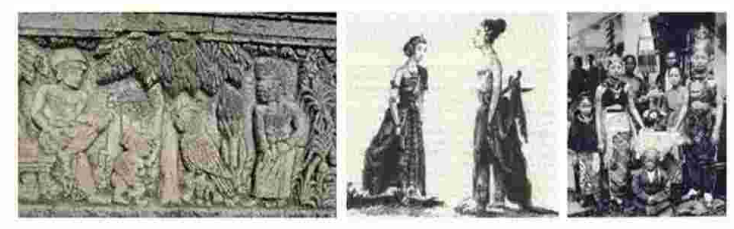

Gambar 2: (a) Relief yang mengisahkan penyatuan Panji-Candrakirana di Candi Panataran-Jawa,

(b) Busana Pengantin Kaum Bangsawan di Wilayah Jawa menjelang abad 19,

(c) Gambar pengantin Sunda (sumber gambar: istimewa).

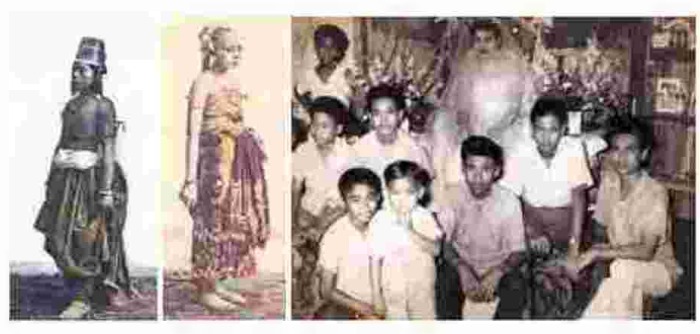

Gambar 3. (a) Busana Pengantin Kaum Bangsawan di Wilayah Jawa menjelang abad 19,

(b) Gambar pengantin Betawipada awal tahun 1960-1970 an (sumber gambar: http://dev.108jakarta.co, istimewa). 


\section{Konsep Kebudyaan Suku Betawi}

Keberadaan masyarakat suku Betawi dapat dikatakan lahir secara bertahap, diawali dengan kisah masyarakat Sunda yang singgah di Kerajaan Tarumanegara dan Pakuan Pajajaran pada awal abad 16, kisah perjanjian raja Kerajaan Sunda dengan bangsa Portugis untuk membangun komunitas di Sunda Kalapa dan dengan beragam peristiwa tersebut maka lahirlah kelompok orang antara tahun 1815-1893 yang membentuk etnis baru akibat dari percampuran perkawinan antar kaum-kaum tersebut. Kata Betawi itu sendiri berasal berasal dari kata "Batavia," yaitu nama lama Jakarta pada masa Hindia Belanda. Sekitar tahun 1930 dapat dikatakan sebagai awal kategori Suku Betawi masuk dalam data sensus, namun keberadaannya belum diakui sah karena keberadaan etnisnya masih berdasarkan lokalitas wilayah mereka bermukim. Pengakuan etnis Betawi selanjutnya terjadi pada tahun 1923, dimana salah satu tokoh Husni Thamrin, yaitu tokoh masyarakat Betawi yang mendirikan Perkoempoelan Kaoem Betawi, juga sebagai tokoh Betawi yang pertama kali menjadi anggota Dewan Rakyat di Hindia Belanda (Volksraad), mewakili kelompok Inlanders. Dengan semangat dan perjuangan yang dibangunnya, maka pada waktu itu pula segenap orang Betawi akhirnya sadar bahwa mereka merupakan sebuah golongan, yakni golongan orang Betawi.

Dengan situasi dan kondisi yang terjadi, faktanya adalah masyarakat Betawi jumlahnya kian menyusut, bahkan jumlah pemukiman atau perkampungan yang dahulu dihuni kaum Betawi sudah mulai banyak menghilang, yang salah satu aspeknya adalah aktifitas pembangunan pemerintahan Indonesia, dan Jakarta sebagai Ibukota, beragam serta aspek politik. Dalam sejumlah catatan sejarah dikisahkan bagaimana nasib para penduduk kampung Betawi yang harus tergusur dari tanahnya sendiri akibat kegiatan pembangunan wilayah dan fasilitas pemerintahan yang sporadis, hingga banyak
Suku Betawi yang akhirnya pergi dan tercerai berai dari lingkunganya sendiri. Dengan berbagai peristiwa tersebut, suku Betawi yang semula adalah wilayah yang didiami banyak kepala keluarga, kini mulai tersebar, dan konsekuensinya adalah mulai terjadinya percampuran dengan etnis pendatang lainnya. Dalam beberapa data lapangan, masih ditemukan pula beberapa kelompok masyarakat Betawi asli yang wilayah bermukimnya menyebar, seperti di Depok, Pasar Minggu, Bendungan Hilir dan lainnya. Konsep kebudayaan dalam sistem kekerabatan masyarakat Betawi berasaskan patrilinear, umumnya mereka menetap dalam dalam satu areal dengan kerabat lainnya yang masih satu keturunan. Begitu pula dalam sistem perkawinan, masyarakat betawi umumnya melakukan perkawinan dengan kerabat atau masih memiliki hubungan kekeluargaan. Keyakinan ini masih ditemui karena mereka meyakini jika menikah dengan orang yang berasal dari luar Betawi, mereka akan mendapatkan musibah dan malapetaka dalam kehidupannya. Dalam interaksi sosial masyarakat Betawi, ada empat aturan yang hingga kini masih dipatuhi dan menjadi panutan bagi mereka, yaitu: (1). jika panggilan waktu sembahyang tiba, mayoritas kaum lelaki bergegas menuju masjid terdekat untuk melaksanakan shalat, pakain yang dikenakan umumnya berwarna putih, celana putih dan berpeci bulat putih; (2) jika ada orang meninggal harus segera dikubur, maka dari itu sering dijumpai banyak kuburan keluarga yang berada di area halaman rumah mereka masingmasing; (3) jika punya anak gadis dewasa, harus segera dinikahkan (4) jika ada tamu harus segara diberi suguhan menurut kemampuan masingmasing keluarga. Dengan masuknya kaum pendatang, tentunya percampuran adat budaya maupun tradisi dalam sistem kebudayaan masyarakat Betawi tidak dapat terhindarkan lagi, yang akhirnya menghasilkan variasi dalam identitas suku Betawi. Hal ini tercermin dalam beberapa hal, seperti dialek, upacara dalam lingkaran keluarga, masyarakat, ungkapan 
simbolik sehari-hari dan lainnya. Namun dari sekian variasi etnik budaya tersebut, identitas suku Betawi dapat dilihat ciri khasnya yag tidak dapat ditinggalkan, yakni sangat kental dalam nuansa ajaran Islam. Bahkan dapat dikatakan agama Islam dijadikan panduan dalam sistem kebudayaan bagi masyarakat Betawi hingga kini dan berlakukan pada setiap aspek kehidupannya sehari-hari.

\section{Busana Pengantin Betawi}

Busana pengantin Betawi memiliki bentuk yang khas, hal ini berkaitan dengan sejarah panjang terbentuknya kota Jakarta sebagai tempat domisili asalnya masyarakat Betawi, yang dikisahkana sebagai kota dagang yang ramai bernama Sunda Kelapa, dan disinggahi oleh berbagai suku bangsa, sehingga budaya masyarakat lokal yang telah terbentuk akhirnya beralkuturasi dengan budaya para pendatang, antaralain dari para pendatang dari Arab, India, Cina, Sunda, Jawa, Eropa, Melayu dan sebagainya.

Pengantin laki-laki secara umum bentuknya sama, yaitu terdiri atas baju panjang yang tertutup sampai batas mata kaki, dan disebut baju kurung/baju koko/gamis. Untuk menutupi bagian luar, pengantin pria mengenakan sejenis selempang yang diselempangkan dari pundak kiri menuju pinggang sebelah kanan. Kemudian dilapis lagi dengan jubah, yang disebut Jube, yaitu pakaian longgar dan terbuka pada bagian depan, sehingga selendang dan gamisnya terlihat dari arah muka. Ketentuannya panjang jubah sekitar $10 \mathrm{~cm}$ lebih pendek dari gamis, dan kain yang digunakan umumnya dari beludru, walaupun kini banyak pula penyedia jasa pengantin yang memberikan alternatif jenis kain yang dipandang lebih ekonomis. Untuk bagian penutup kepala, disebut alpie, yaitu penutup kepala khas haji, bentuknya menyatu dengan kain surban dan digulung sedemikian rupa, dibagian sisi biasanya dihiasi untai melati, mawar dan cempaka di bagian ujungnya. Untuk kostum pengantin perempuan umumnya terdiri dari baju bagian atas berhias sulaman dan manikmanik, bentuk leher umumnya tertutup yang disebut kerah shanghai yang disebut tuaki. Bagian bawah berupa rok yang potongannya melebar disebut kun. Pada bagian atas, terdapat hiasan penutup dada yang disebut Delime Betawi atau Teratai Betawi. Bagian kaki digunakan sejenis selop yang disebut Perahu Kolek. Untuk bagian kepala digunakan sanggul buatan yang digulung ke atas. $\mathrm{B}$ a $\mathrm{g}$ i a $\mathrm{n}$ aksesoris digunakan ronce melati dan siangko cadar, berupa hiasan dahi yang mirip cadar, terbuat dari manik-manik berwarna emas dan berjuntai hingga menutupi wajah dan beberapa perhisan lainnya, seperti Burung Hong: yaitu berupa tusuk di bagian rambut berukuran panjang dan dibagian ujungnya terdapat replika Burung Hong, khas aksesoris China. Kemudian Kembang yang digunakan sebagai aksesoris pada bagian kepala, antara lain kembang goyang, kembang kelape dan kembang rumput.
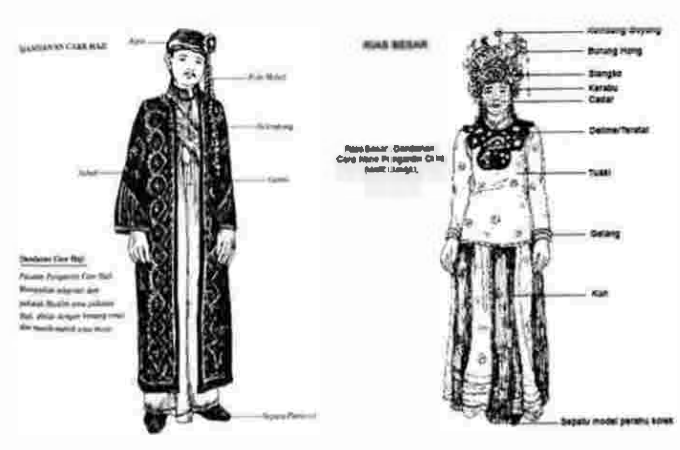

Gambar 4. Ilustasi Busana Pengantin Betawi
(Sumber: Istimewa).

\section{Unsur Rupa dan Makna pada Busana Pengantin Betawi Pria.}

\section{a. Jubah}

Unsur rupa yang ada pada busana pengantin Betawi baik pada pengantin pria maupun wanita. tidak terdiri atas satu baju atau pakaian saja, melainkan terdiri atas beberapa unsur yang keberadaannya dapat diurai menjadi beberapa kelengkapan, yaitu unsur kelengkapan atas, unsur kelengkapan bawah dan aksesoris. Unsur 
kelengkapan atas adalah unsur yang digunakan sebagai penutup tubuh di bagian atas hingga batas pinggang, dan unsur kelengkapan bawah adalah apa yang digunakan oleh pengantin pada bagian pinggang hingga mata kaki. Jubah adalah unsur kelengkapan yang digunakan di bagian tubuh paling luar oleh pengantin pria Betawi. Konsep penggunaan jubah ditemukan hampir disemua kebudayaan, seperti budaya Budha, India, Cina, Arab, hingga Eropa, perbedaan terletak pada aspek bentuk, nama dan istilah yang berbeda. Dalam bahasa Sanskerta jubah disebut dengan istilah civara, dan para abdi Budha Gautama menggunakan jubah yang dinamakan Kasaya. Jubah yang digunakan oleh pengantin pria Betawi lebih menyerupai jubah yang berasal dari daratan Arab, jika dirunut kebelakang, sejarah terbentuknya suku Betawi memang tidak lepas dari kontak budaya yang terjalin antar masyarakat setempat dengan para pedagang di pelabuhan Sunda Kelapa pada abad ke-12, dimana kapalkapal asing yang berasal dari berbagai wilayah seperti Tiongkok, Jepang, India Selatan, dan'Timur Tengah berniaga sekaligus menjalin kontak budaya dengan masyarakat setempat. Di masa Rasul, jubah telah digunakan sebagai kelengkapan pakaian sehari-hari, dikenal dengan istilah burdah. Keberadaan jubah atu burdah itu sendiri tidak lepas dari kisah seorang kafir yang bertobat diberikan penghormatan oleh Rasulullah berupa jubah, sebagai simbol bahwa dosanya telah diampuni, kemudian burdah ini dibeli oleh Khalifah Mu'awiyah bin Abi Sufyan, juga Khalifah Abu Ja'far al-Manshur, yang digunakan setiap shalat ied, dan akhirnya diteruskan secara turun temurun hingga saat ini.

Jubah yang digunakan oleh pengantin Betawi umumnya berbentuk longgar dan besardengan aplikasi hiasan benang emas dan manik, membentuk motif burung hong, bungabungaan, kubah mesjid, pola geometris dan lain sebagainya. Prinsip dasar dari jubah daratan Arab adalah terbuka pada bagian depan, hingga memperlihatkan pakain pelapis bagan dalam, yaitu gamis. Sebelum mengenakan jubah, pengantin laki-laki harus memakai gamis sebagai bagian baju dalaman, umumnya berwarna muda yang panjangnya sampai mata kaki dan berwarna polos, tanpa ornamen sama sekali. Dalam wacana Islam, penggunan jubah dikaitkan dengan riwayat Rasul, seperti yang diungkapkan di atas, tentunya hal ini pun menjadi makna tersendiri bagi masyarakat Betawi yang memang sangat erat dengan nilai ke-Islaman pada setiap aspek kehidupannya. Penggunaan jubah pada pengantin pria dapat dikonotasikan sebagai simbol kereligiusan mereka dalam beragama, simbol penghormatan terhadap kebesaran Rasul sang penyempurna ajaran Islam, sekaligus simbol keagungan, karena bagaimanapun dalam agama Islam, perkawinan masih dianggap sebuah peristiwa yang suci, agung dan sakral. Dari aspek rupa, bentuk jubah, konsep penggunaan jubah termasuk ornamen yang diaplikasikan, terlihat sebuah proses pencampuran budaya yang harmonis, namun tetap memiliki spirit terhadap nilai historis bagi masyarakat Betawi khususnya. Walau tidak diketahui kapan pastinya penggunaan jubah dalam sebuah tatacara perkawinan mulai digunakan, namun hal ini menunjukkan perilaku percampuran budaya yang begitu harmonis, hingga keseluruhan nilai simbolik yang walau dilatarbelakangi kebudayaan yang berbeda, namun keseluruhannya tetap menjaga agar elemen yang hadir tetap mengusung sakralitas sebuah peristiwa yang suci mengandung berkah, doa harapan dan yang dilekatkan pada sebuah jubah, yang akan digunakan oleh sang penagntin pria. Beberapa motif yang diapliaksikan pada Jubah unumnya berupa stilasi sederhana, berupa ornamen geometris dan suluran. 


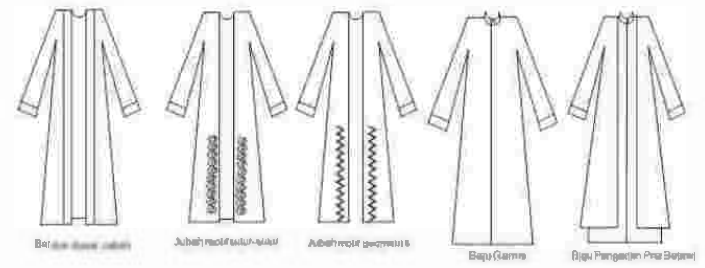

Gambar 5. Ilustrasi Jubah, Gamis dan motif yang digunakan (Sumber: ilustrasi penulis 2018)

\section{b. Alpie}

Penutup kepala, yang dililit oleh sorban sedemikian rupa, berwarna putih atau terang, dan berhiaskan ornamen tertentu dari manik atau sulaman. Secara bentuk, penutup kepala yang digunakan oleh pengantin laki-laki yang saat ini digunakan tampak sudah mengalami pergeseran dan penyederhanaan bentuk. Secara prinsip, bentuknya lebih kecil dari aspek ukuran, kemudian lilitannnya tidak terlalu banyak atau tebal seperti alpie yang digunakan oleh para raja atau kerabat Sultan Arab di masa lalu. Bentuk alpie yang digunakan pada masa Kerajaan Arab cenderung polos, tidak ada untaian bunga dan aksesoris lainnya, sedangkan alpie yang digunakan pengantin laki-laki umumnya dihiasi roncean bunga melati sebanyak 3 untai, bagian ujung bawahnya diberi bunga cempaka, dan bagian atasnya ditampeli mawar merah.
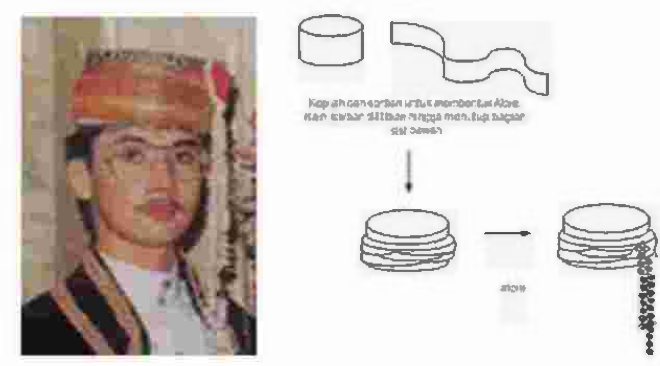

Gambar 6. Contoh Penggunaan Alpie dan Modifikasinya (sumber: weddingku.com, bensradio.com)

Di Indonesia penggunaan bunga tidak semata sebagai aksesoris atau penghias semata, melainkan memiliki makna simbolis, bahkan kisah-kisah historis yang dimaknai sebagai bentuk penghormatan sekaligus keagungan. Secara sederhana mengapa bunga melati sering digunakan sebagai roncean karena bunga melati dari aspek fisiologis berwarna putih dan menyebarkan wangi yang khas, dan sering disimbolkan pada nilai kesucian, ketulusan dan kebersihan hati. Keberadaan bunga Melati dalam budaya masyarakat Indonesia dapat ditemukan di semua wilayah, terutama Melayu, Betawi, Jawa, Sunda, Madura dan Bali, selain bermakna kesucian, melati juga melambangkan nilai kesuburan, kesejahteraan dan kemakmuran. Karena dalamnya makna simbolis pada bunga melati inilah, para penyelenggara adat selalu menghadirkan melati baik dalam roncean maupun taburan, bahkan ada keyakinan dimana bila ada pengantin yang tidak melilitkan ronce melati pada keris yang dipakainya, dianggap kurang sempurna dalam menjalani pernikahannya. Dapat ditarik sebuah analisa bahwa Alpie yang erat berkait dengan nilai ajaran Islam dimaknai sebagai penutup kepala bahwa laki-laki disunnahkan menggunakan penutup kepala saat beribadah, sekaligus simbol kepatuhan dan keimanan calon pengantin lakilaki pada saat memasuki jenjang pernikahan. Berkait dengan penempatan makna bahwa lakilaki yang telah berani melangkahkan kakinya untuk menikah, memasuki hidup baru, ia harus menjadi pemimpin yang baik,

\section{Unsur Rupa dan Makna pada Busana Pengantin Betawi Wanita}

\section{a . Siangko}

Adalah hiasan kepala yang digunakan pada pengantin perempuan, siangko bercadar melambangkan kesucian seorang gadis, umumnya dari meterial emas atau bahan perak. dihiasi batu-batu permata, bahkan ada yang bertahtakan intan berlian. Panjang cadarnya 30 $\mathrm{cm}$, terbuat dari manik-manik. Saat ini banyak digunakan mote pasir dengan gumpalan benang wol merah di ujungnya. Selain yang bercadar, siangko lainnya jumlah 3 (tiga) buah. Dipakai di belakang sanggul sebagai penutup ikatan siangko bercadar. Siangko bercadar yang 
berfungsi menutupi wajah pengantin wanita merupakan lambang kesuciannya, yang disimbolkan dengan tidak boleh dilihatnya wajah mempelai putri oleh orang lain. Di atas Siangko bercadar ini, diletakkan sigar atau mahkota dengan motif bunga berhiaskan permata. Hiasan rambut lainnya adalah tusuk paku atau kembang paku berjumlah 10 buah atau lebih yang dimaksudkan sebagai penolak bala. Tusuk bunga atau kembang tancep berjumlah 5 buah yang melambangkan rukun Islam, sebuah kewajiban yang harus dijalankan oleh pengantin sebagai seorang Muslim. Kembang goyang berjumlah 20 buah, juga dikarenakan sebagai hiasan rambut bersama dengan 2-4 buah kembang kelapa yang dipasang di kiri dan kanan sanggul. Apabila kembang goyang melambangkan pengakuan terhadap 20 sifat kebesaran Allah, yang wajib diturunkan dan diajarkan pada anak keturunannya kelak; maka kembang kelapa merupakan simbol pengharapan agar perkawinan yang dilakukan tetap kokoh, kuat seperti pohon kelapa, sehingga akan menjadi perkawinan yang langgeng, sejahtera dan bahagia. Hiasan burung hong atau dikenal dengan sebutan kembang besar atau kembang gede adalah hiasan lain yang tidak boleh ketinggalan. Jumlahnya yang empat buah melambangkan empat sahabat Rasullullah, Nabi Besar Muhammad SAW. Sementara itu, burung hong sendiri dianggap sebagai simbol burung surga yang melambangkan kebahagiaan kedua pengantin.
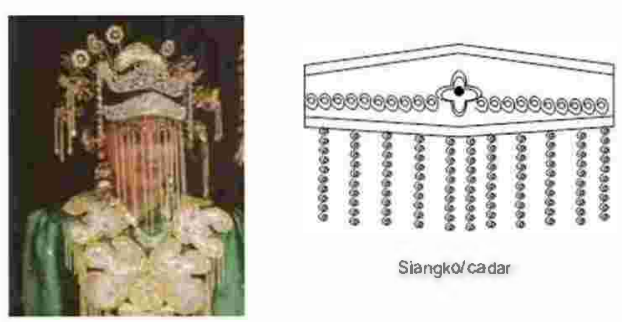

Gambar 7. Siangko bercadar (sumber gambar: istimewa)
Letak burung hong ini juga memiliki arti tersendiri, yang berkaitan dengan kecocokan antara pihak keluarga kedua pengantin. Dari hiasan kepala pengantin wanita yang telah dikemukakan, satu bentuk perhiasan yang dipercaya memiliki kekuatan magis adalah sunting atau sumping telinga. Apabila sunting ini dipakai oleh seorang pengantin yang tidak perawan atau tidak gadis lagi, maka si pemakai akan pusing-pusing dan bahkan pingsan. Selain sunting, sebagai pelengkap yang menunjang keserasian, biasanya telinga pengantin dihias dengan sepasang kerabu. Kerabu ini merupakan perpaduan anting dan giwang yang dijadikan satu. Tusuk konde berupa pasak berbentuk huruf leam (huruf Arab) merupakan simbol pengakuan akan keesaan Allah ditusukkan di atas siangko kecil penutup simpul tali cadar. Makna filosofis lainnya yang dapat diungkap pada penggunaan hiasan di atas adalah hiasan berupa burung Hong atau phoenix. Hiasan ini ternyata ditemukan pula pada pengantin perempuan Cina. Secara geografis, Jakarta yang merupakan wilayah etnis masyarakat Betawi adalah masyarakat pesisir, dan unsur serapan atau pencampuran budaya lokal dengan pendatang umum terjadi dan membentuk kebudayaan baru. Burung Hong atau phoenix, binatang mitologi, yang dianggap agung dan diyakini sebagai salah satu dari empat binatang yang dianggap sakral. Burung Hong atau Phoenix disebut huga Fheng Huang, disimbolkan sebagai penyatuan antar jantan dan betina, perempuan dan laki-laki, dan digunakan pada sebuah acara resepsi pernikahan.

\section{b. Baju Tuaki dan Rok Kun}

Setelah budaya Betawi semakin menguat keberadaan dan identitasnya, maka dalam aspek busana pun terdapat elemen tambahan dan beberapa perubahan yang menjadikan pakaian adat ini semakin memperjelas identitas busana pengantin ini adalah milik kebudayaan rakyat Betawi. Detail dari busana yang dikenakan oleh pengantin perempuan terdapat campuran 
dengan budaya Cina, seperti bentuk dan warna. Nuansa merah yang mendominasi busana pengantin dikaitkan dengan kayakinan kebudayaan Cina, warna merah disebut Hong, dan disebut warna sakral, yang bermakna yang sangat positif, dan diyakin erat dengan energi baik, seperti kegembiraan, sumber kegembiraan, berkait dengan sinar kecerahan, keteguhan, keberanian, keceriaan sekaligus ekspresi kemegahan. Kebudayaan bangsa Cina meyakini bahwa elemen warna tersebut yang menjadikan segala isi alam raya, dan warna tersebut datang secara alami ke dunia. Lima elemen warna tersebut yakni air, kayu, logam, tanah dan air dan jika diurutkan elemen warna tersebut berurutan menjadi beberapa pecahan warna, yakni hitam, merah, biru, hijau dan kuning. Dan warna merah diyakini sebagai warna yang melambangkan suka cita, keberuntungan dansegalahal yang bermaknapositif, dan kebudayaan serapan itulah yang tercermin dalam penggunaan warna bagi pengantin perempuan dan laki-laki di masyarakat Betawi.

Rok yang digunakan pada busana pengantin Betawi disebut Kun, terbuat dari bahan sutra dengan manik-manik dan gambar burung Hong (phoenix). Busana ini menyerupai pakaian yang dikenakan pengantin pada masa kekaisaran. Dalam peta sejarah peradaban bangsa Cina menempatkan diri sebagai bangsa yang memiliki konsep yang terdepan dalam hal busana, upacara dan norma, karena dalam setiap bentuk busana/kostum yang dihasilkan selalu ditanamkan unsur filsafa tradisional dalam pembentukannya. Detail pembagian bentuk kostum bagian atas dan bawah terlihat pada gambar di atas. Bentuk pakaian atas dengan lengan panjang, berbentuk lurus, memperlihatkan makna kesederhanaan, kesucian, memperlihatkan pola yakni baju Tuaki dan rok kun, pada gambar di atas memperlihatkan detail bentuk, sangat kental dengan unsur serapan kostum Cina, dimana salah satu yang paling berpengaruh dan terkenal masa peradaban Cina dan mendominasi adalah model Hanfu, yang pengaruhnya menyebar hingga ke wilayah lain seperti Jepang, Korea, Vietnam dan Indonesia.

Konsep pakaian jenis Hanfu, umumnya berlengan lebar, dengan jahitan lurus, potongan dibuat melingkar, dan melebar pada bagian bawah, dan bentuk ini yang ditemukan pada busana pengantin perempuan, dimana berbentuk lurus, dan hanya memperlihatkan kaki dan jari tangan. Makna dari bentuk kostum yang lurus, tertutup dan hanya memperlihatkan sedikit bagian tubuh menyimbolkan makna kesantunan, kesederhanaan, dan dapat digunakan oleh segala usia, tanpa memperlihatkan bentuk tubuh yang berlebihan.

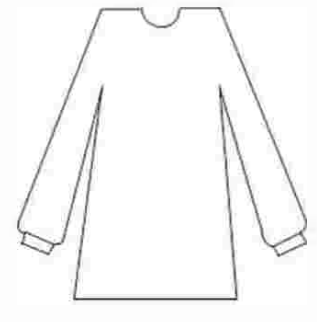

Baju Tuaki

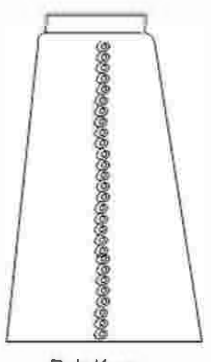

Rok Kun
Gambar 8. Ilustrasi Rok Kun dan BajuTuaki (Sumber:ilustrasipenulis 2018)

\section{c. Sanggul}

Sanggul pengantin Betawi perempuan, umumnya berupa sanggul buatun atau konde cepol tanpa sasakan. Caranya adalah dengan melilitkan secara berputar, sehingga membentuk 3 tingkat lingkaran, yang kemudian dipadatkan dengan tusuk konde. Proses pembentukan sanggul pun ada beberapa tahap yang umumnya dilakukan pada masyarakat Betawi, sebagai berikut, dimana setelah rambut diikat ketat, rambut dililit di setiap putaran dengan kencang. Hal yang tidak dilewatkan adalah saat penyusunan sanggul, tradisi yang digunakan masyarakat lama adalah rambut diisi dengan pelepah pisang dan irisan daun pandan yang dengan tujuan untuk memudahkan proses 
pembentukan sanggul serta menjadi pengharum alami bagi sanggul si pengantin perempuan. Bentuk dan letak sanggul umumnya berada di tengah-tengah agak ke atas, dan harus memperlihatkan tengkuk pengantin. Masyarakat Betawi meyakini, apabila kondisi tengkuk mempelai pengantin perempuan terlihat bersih, maka hal itu merupakan tanda bahwa sang perempuan kelak menjadi ibu rumah tangga yang baik, dan mampu memelihara kebersihan fisik dan rohani dalam kehidupan rumah tangganya.

Teknik menghias rambut pada perempuan kemungkinan besar telah ada sejak masa prasejarah, dimana dari hasil temuan artefak kuna, terdapat beberapa jenis barang yang diduga berupa manik-manik penghias rambut. Bahkan jika kita perhatikan pada relief maupun ilustrasi pada naskah-naskah kuna, rambut Ketiga tingkat lingkaran ini melambangkan siklus kehidupan yang dimulai dari kelahiran, kehidupan dan kematian. Dalam tinjauan sejarahnya, sanggul cepol, yang digunakan para perempuan Betawi ada beberapa jenis dengan penggunaanya yang berbeda. Dan yang biasa digunakan oleh pengantin adalah umumnya bentuk sawi asin dan sanggul cepol buatun. Sanggul cepol kental dengan budaya serapan dari Cina, dalam sejarahnya sanggul telah dikenal sejak masa Mesir Purba, selalu digunakan pada kegiatan yang berkaitan ritual bahkan menandakan status sosial.

\section{KESIMPULAN}

Pada unsur rupa kostum pengantin Betawi ternayata memiliki aspek makna simbolis, ditemukan beberapa makna yang memperlihatkan keluhuran nilai dan ragam filosofis, cermin berbaurnya beragam budaya, seperti kebudayaan masyarakat lokal Betawi, China, Arab. Tidak semua makna dapat tergali dengan baik, mengingat banyak data yang tidak dapat digali dengan maksimal, karena sering terjadi persepsi dan pemahaman yang bergeser seiring waktu baik, yang dampaknya juga mempengaruhi pada tampilan visual dan rupa, juga pada bentuk, warna, motif atau ornamen yang digunakan. Temuan yang paling menarik pada kostum pengantin Betawi ini adalah pada kostum pengantin perempuan kental dengan kebudayaan Cina, namun pada kostum laki-laki, kental dengan nuansa budaya Arab, dan seperti kita ketahui bahwa dalam sejarahnya dua kebudayaan ini memang sangat memberikan pengaruh yang kuat pada perkembangan dan pertumbuhan masyarakat Betawi. Namun untuk warna, kebudayaan Cina sangat berperan, hingga saat ini elemen warna merah mendominasi pada ornamen dan beberapa kelengkapan yang digunakan.

\section{DAFTAR PUSTAKA}

LATUMINGGI, APRILLIO, DKK.

2007. Kebudayaan Suku Betawi.

Sekolah Tinggi Akuntansi Negara.

\section{HERLIYONO.}

2010. Melati Ronce. Babad Tanah Jawi dan Babad Pajang.

Pemerintah DKI.

2000. Busana Betawi, Sejarah dan Prospek Pengemban ganniya. Dinas Museum dan Pemugaran, Pemerintah DKI.

Fakultas Ilmu Pengetahuan Budaya.

2011. Langgam Budaya Betawi; Fakultas Ilmu Pengetahuan Budaya, Universitas Indonesia.

Fakultas Ilmu Penegtahuan Budaya.

2012. Rupam Gaya, Rasa Betawi. Fakultas Ilmu Pengetahuan Budaya, Universitas Indonesia. 


\section{DAFTAR ONLINE}

http://media.isnet.org/isnet/Nadirsyah/Jubah.html

1. www.bensradio.com

2. http://www.jakarta.go.id/web/encyclopedia/ detail/414/Dandanan-Care-Haji

3. Mahligai Majalah,

4. ht tp:// siapbelajar.com / w p content/uploads/2013/09/122_214TataKecantikan-Rambut-Jilid-2.pdf

5. yogyakartamycity.blogspot.com http:/ / ww w.cnnindonesia.com/gayahidup/20150218141016-269-33107/maknamerah-dan-emas-pada-semarak-imlek

6. http://nationalgeographic.co.id/berita/2014 /11/hakikat-makna-burung-phoenix-dalamtradisi-cina

7. http://pakaiantradisionalcina.blogspot.co.id/ 2015/03/1.html

8. http://michanathere.blogspot.co.id/2011/05 /pakaian-tradisional-bangsa-han-china.html 